\title{
Immune-endocrine interactions affecting luteal function in pigs
}

\author{
W. Wuttke, L. Pitzel, I. Knoke, K. Theiling and H. Jarry \\ Division of Clinical and Experimental Endocrinology, Department of Obstetrics and Gynecology, \\ University of Göttingen, Germany
}

\begin{abstract}
The formation, normal function and destruction of corpora lutea are essential features of normal reproduction. Although the formation of corpora lutea from follicles is largely dependent on pituitary gonadotrophins, the process of luteolysis is locally regulated and poorly understood. The corpus luteum consists of several steroidogenic and nonsteroidogenic cell types that interact with each other in a paracrine manner. Under cell culture conditions, large luteal cells that stem from follicular granulosa cells can be identified easily under the microscope and collected individually for single cell RT-PCR. As each of the 120 large luteal cells express the gene encoding $3 \beta$-hydroxysteroid dehydrogenase, it appears that all large luteal cells are steroidogenic. Large luteal cells also express the oestrogen receptor gene and as they are known to produce oestradiol, it can be concluded that the steroid acts in an auto- or intracrine manner in large luteal cells. Since we showed previously that oestradiol stimulates progesterone release under in vitro and in vivo conditions, it can be concluded that the steroid is an important intraluteally acting luteotrophic signal. At the time of luteal regression, macrophages invade the corpora lutea and their cytokine products, particularly tumour necrosis factor $\alpha$ (TNF $\alpha$ ), appear to be involved in reduced steroid secretion. Indeed, TNF $\alpha$ inhibits production of progesterone and oestradiol from cultivated luteal cells. In sows, oestradiol is a strong luteotrophic factor and the production of oestradiol and of its receptor is downregulated by TNF $\alpha$. Thereby, TNF $\alpha$ not only exerts direct luteolytic effects but also prevents the luteotrophic effects of oestradiol. Hence, it has an anti-luteotrophic action. In most species, functional luteolysis is accompanied by morphological regression of the corpus luteum. This structural luteolysis also appears to involve TNF $\alpha$, as we have shown in pigs that expression of TNF $\alpha$ gene is high during luteolysis. Furthermore, TNF $\alpha$ stimulates programmed cell death (apoptosis) in luteal cells kept under culture conditions.
\end{abstract}

\section{Introduction}

It is well known that the normal function of the corpus luteum is largely dependent on pulsatile LH secretion. However, there is evidence that paracrine regulatory processes are also essential for normal luteal function (Adashi et al., 1990). For example, it has been demonstrated that oxytocin, a peptide produced in steroidogenic large luteal cells, is an important luteotrophic factor for the normal function of the corpus luteum (Jarry et al., 1990); however, towards the end of its lifespan the corpus luteum becomes luteolytic (Wuttke et al., 1995). Little is known about the process of luteolysis, which occurs spontaneously even though normal pituitary gonadotrophin support is maintained. In pigs, the presence of the uterine endometrium, which secretes the luteolytic substance prostaglandin $\mathrm{F}_{2 a}\left(\mathrm{PGF}_{2 \alpha}\right)$, is essential for luteolysis. However, there is also evidence that $\mathrm{PGF}_{2 \alpha}$ is produced not only by the endometrium but also by the cells of the corpus luteum (Patek and Watson, 1976). When $\mathrm{PGF}_{2 \alpha}$ is administered directly into the corpus luteum, it increases the secretion of oestradiol and progesterone (Jarry et al., 1990). However, under monolayer cell culture conditions, the ecosanoid has a direct inhibitory effect on progesterone secretion, whereas oestradiol is stimulated (Pitzel et al., 1993a,b). In addition, it was shown that oestradiol stimulates progesterone 


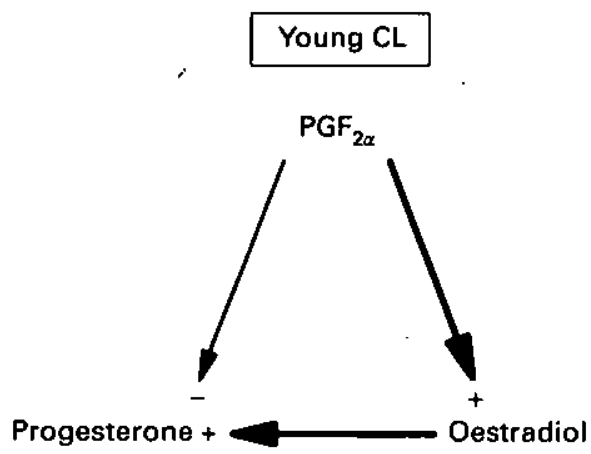

Fig. 1. Prostaglandin $F_{2 a}$ has a direct stimulatory effect on oestradiol production by luteal cells but indirectly inhibits progesterone secretion. In the fully functioning corpus luteum, the $\mathrm{PGF}_{2 \alpha}$-stimulated oestradiol overrides the direct inhibitory effects of the eicosanoid and this is indicted by the thickness of the arrows. Hence, $\mathrm{PGF}_{2 a}$ stimulates progesterone secretion.

secretion. On the basis of these results, we hypothesized that in fully functioning corpora lutea, $\mathrm{PGF}_{2 \mathrm{a}}$ stimulates so much oestradiol that the direct inhibitory effect on progesterone secretion is overcome by oestradiol such that $\mathrm{PGF}_{2 \alpha}$ has a direct oestradiol-mediated stimulatory effect on progesterone secretion (see Fig. 1). Hence in non-regressing corpora lutea, $\mathrm{PGF}_{2 \alpha}$ has a luteotrophic function. The mechanisms by which $\mathrm{PGF}_{2 a}$ becomes luteolytic are largely unknown and the evidence that cells stemming from the white blood cell line, particularly macrophages, are important factors for the induction of luteolysis will be reviewed.

\section{The Luteotrophic Oestrogenic Mechanism}

We have recently shown that oestradiol stimulates progesterone release from pig luteal cells under in vitro culture conditions (Pitzel et al., 1993a,b). Conley and Ford (1989) and Pusateri et al. (1996) have demonstrated that oestradiol lengthens the luteal phase of gilts in vivo, which also points to a luteotrophic or anti-luteolytic effect of the steroid. Using a microdialysis system that can be implanted in corpora lutea (CL) and that functions like an artificial capillary with exteriorized inlets and outlets (Jarry et al., 1985), we demonstrated that an intraluteal application of oestradiol stimulates progesterone release in freely moving sows (Jarry et al,, 1990). Furthermore, we demonstrate now that this luteotrophic effect of oestradiol is most prominent during the early and mid-luteal phases and declines at the time of luteal regression (Fig. 2); at day 8 of the luteal phase oestradiol stimulates progesterone secretion. At the time of luteolysis this effect is no longer seen. The mechanism of action and the luteal cell type in which oestradiol stimulates progesterone secretion remains unknown. Earlier attempts to demonstrate oestradiol receptors in luteal tissue by means of immunocytochemistry or with molecular tools failed (Hild-Petito et al., 1988; Chandrasekher et al., 1994). Therefore, we applied the reverse transcription-polymerase chain reaction (RT-PCR) using primers that identified expression of the oestradiol receptor gene in tissues known to contain such receptors and tried to quantify mRNA encoding the oestradiol receptor in pig luteal tissue at different times of the luteal phase and in corpora lutea of pregnancy. The intensity of the PCR product staining was high in luteal tissue obtained during the early and mid-luteal phase and low in corpora lutea undergoing regression (Fig. 3). Expression of the oestradiol receptor gene remained high in luteal tissue obtained from pregnant gilts. A quantitative evaluation of all PCR 

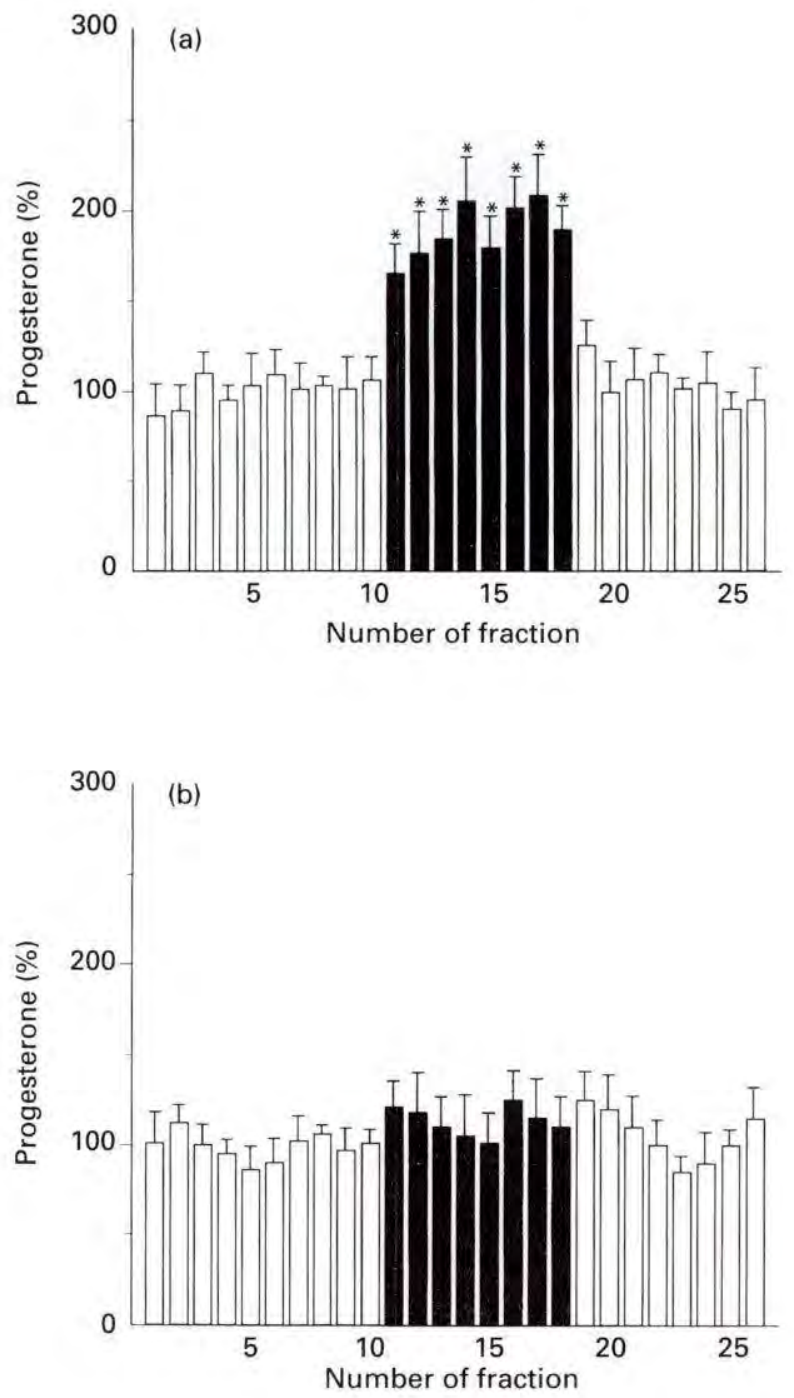

Fig. 2. Effects of an intraluteal application of oestradiol on progesterone secretion of corpora lutea at (a) day 8 and (b) day 12 of the luteal phase. The corpora lutea $(n=8)$ of three sows were implanted with a microdialysis system (Jarry et al., 1985, 1990) at day 7 of the luteal phase and oestradiol $\left(10^{-6} \mathrm{mmol} \mathrm{l}^{-1}\right)$ dialysed (․ㅡ) into the corpora lutea at day 8 and 12. Effluent fractions were collected at intervals of 30 $\min$. Note that oestradiol stimulates progesterone secretion at day 8 but not at day 12. Progesterone values in the ten fractions collected before application of oestradiol were set as $100 \%$. Asterisks indicate significantly increased progesterone concentrations in the dialysates $(P<0.05)$. 

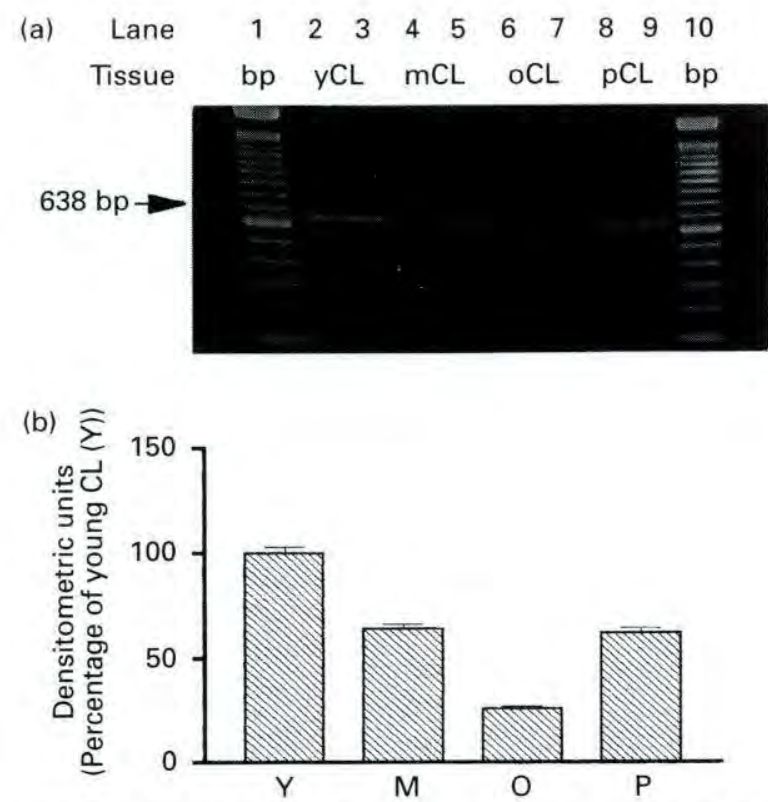

Fig. 3. Expression of the oestradiol receptor gene in pig corpora lutea at various stages of the luteal phase. (a) RT-PCR products using primers for mRNA encoding the oestradiol receptor from pig luteal tissues at various times of the luteal phase. Lanes 1 and 10 show the $100 \mathrm{bp}$ ladder. Lanes 2 and 3 show products of young corpora lutea (yCL, collected at day 3 or 4 of the luteal phase); lanes 4 and 5 show products of middle-aged corpora lutea (mCL, collected at day 7 or 8) and lanes 6 and 7 show products of old, regressing corpora lutea (oCL, collected at day 12 or 13). Lanes 8 and 9 show products of corpora lutea of pregnancy ( $\mathrm{pCL}$, collected at day 27 of pregnancy). (b) Densitometric quantification of the PCR products shows progressively lower expression of the oestrogen receptor gene as the corpora lutea age; expression remains high in the corpora lutea of pregnancy. For statistical evaluation, the mean densitometric units obtained for PCR products from young corpora lutea were set as $100 \%$ and the other values adjusted accordingly. Asterisks indicate significantly different values $(P<0.05)$ compared with the values obtained in young corpora lutea.

products by densitometry $(n=10)$ confirms these observations (Fig. 3). Hence, at times of the luteal phase when oestradiol can stimulate progesterone secretion (see Fig. 2), expression of the oestradiol receptor gene is high and decreases at the time of luteal regression when oestradiol no longer stimulates progesterone secretion. In corpora lutea of pregnancy, oestradiol remained stimulatory to progesterone secretion (data not shown) and consequently expression of the oestradiol receptor gene is high in these corpora lutea (Fig. 3).

\section{Which Luteal Cell Type Expresses the Oestradiol Receptor?}

The corpora lutea of all species studied so far consist of several steroidogenic and non-steroidogenic cell types (Fitz et al., 1982; Alila and Hansel, 1984; Brannian et al., 1993; Schwall et al., 1986; Pitzel et 


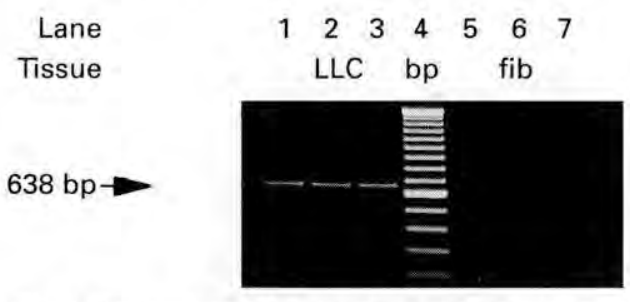

Fig. 4. Expression of oestrogen receptor gene in $3 \times 30$ large luteal cells (LLC) and in $3 \times 30$ fibroblasts (fib). Note that the LLC express the oestrogen receptor gene, which is not the case in fibroblasts.

al., 1990). The two steroidogenic cell types stem from the two follicular compartments, i.e. granulosa cells develop to so-called large luteal cells (LLC), whereas the follicular theca cells develop to small luteal cells (SLC). These two types of cells are not the most abundant cells in the corpus luteum; because of the rich capillary blood supply, the non-steroidogenic endothelial cell is the most common cell in luteal tissue (O'Shea et al., 1986). Besides these non-steroidogenic cells, there are fibroblasts and cells stemming from the white blood cell line (Kirsch et al., 1981; Hehnke et al., 1994; Adashi et al., 1990). Under the microscope, because of their size ( $>25 \mu \mathrm{m})$, the LLC are easiest to distinguish from other cell types maintained under culture conditions. We therefore developed a tool that allowed us to collect individual LLC using a stereotaxic microdrive and a micropipette that enabled us to aspirate individual LLC into the pipette and to transfer them individually into vials for

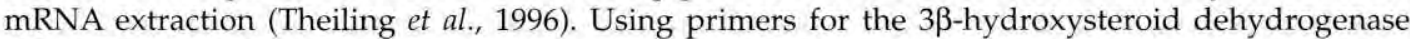

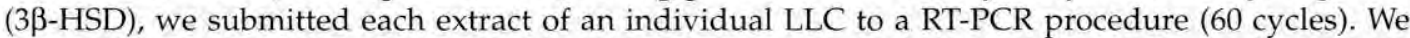
were able to demonstrate that each of 120 LLC submitted to this procedure expressed the $3 \beta-H S D$ gene. Hence, we conclude that each large luteal cell is steroidogenic. For comparison, we submitted fibroblasts of luteal origin, which can also be distinguished from other cell types under the microscope, to the same procedure and demonstrated that none of the fibroblasts express the $3 \beta$ HSD gene. With this knowledge, we harvested greater numbers of LLC (30 per vial), extracted their RNA and studied whether less abundantly expressed genes, such as the oestradiol receptor gene, are also expressed by this cell type. Figure 4 shows clearly that oestradiol receptor gene expression can be demonstrated in LLC but not in fibroblasts. Hence, the steroidogenic LLC also express the oestradiol receptor gene and it can be concluded that oestradiol, which is produced by LLC, exerts an auto- or intracrine effect in LLC. Unfortunately, other cell types, such as the SLC, the endothelial cells and cells stemming from the white blood cell line, including macrophages, cannot be easily distinguished from each other in freshly prepared and dispersed luteal cells. Therefore, we were unable to perform single cell PCR in any of these cell types. Hence, the question of whether or not the steroidogenic SLC and other non-steroidogenic cells also express the oestradiol receptor gene remains unanswered.

\section{What Causes Downregulation of the Expression of the Oestradiol Receptor Gene at the Time of Luteal Regression?}

There is ample evidence that, at the time of luteal regression, macrophages invade the pig corpus luteum (Adashi et al., 1990). The major products of macrophages are tumour necrosis factor $\alpha$ (TNF $\alpha$ ) and a variety of interleukins (IL), including IL-1 (Kennedy and Jones, 1991). Both cytokines have been shown to inhibit progesterone and oestradiol release (Pitzel et al., 1993b). An increased production of TNF $\alpha$ at the end of the luteal phase was demonstrated using an in vivo microdialysis system (Shaw and Britt, 1995). During inflammatory processes, macrophages can be activated to increase TNF $\alpha$ secretion by bacterial lipopolysaccharides (LPS) (Kennedy and Jones, 1991). Since 


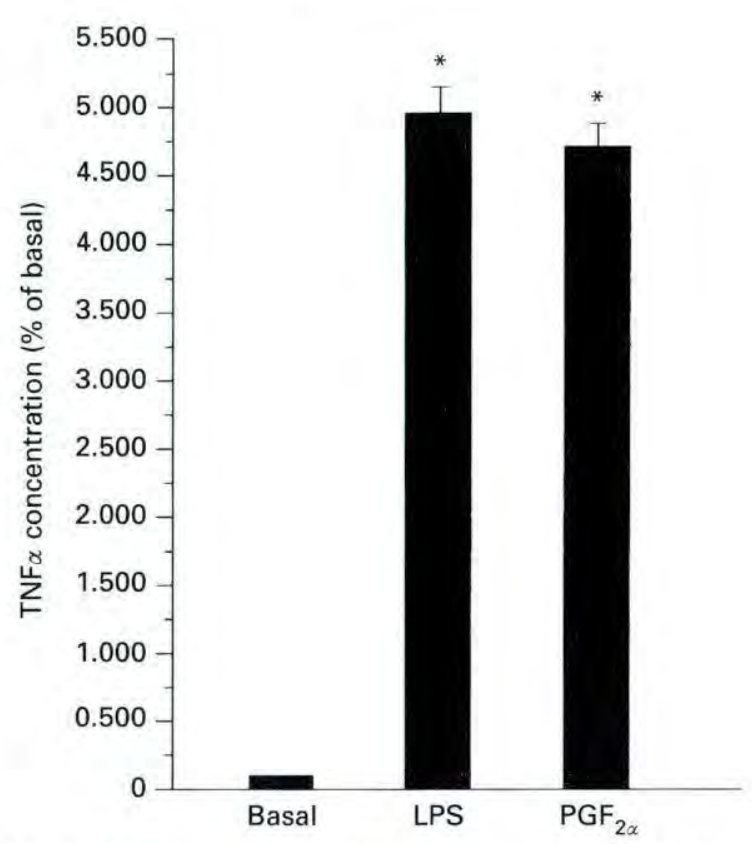

Fig. 5. The growth of a mouse fibrosarcoma cell line (WeHi cell) is inhibited by TNF $\alpha$ in a dose-dependent manner and this can be used as a basis for a highly sensitive in vitro bioassay. When macrophages are kept under culture conditions, their TNF $\alpha$ production is low compared with production under the influence of bacterial lipopolysaccharides (LPS $5 \mu \mathrm{g} \mathrm{ml}^{-1}$ ) or $\mathrm{PGF}_{2 \alpha}$ $\left(10^{-7} \mathrm{~mol} \mathrm{l}^{-1}\right)$. Hence, $\mathrm{PGF}_{2 \alpha}$ is a potent stimulator of macrophage TNF $\alpha$ secretion. Basal TNF $\alpha$ production by macrophages is set as $100 \%$ and the LPS and $\mathrm{PGF}_{2 \alpha}-$ stimulated values are corrected accordingly. Asterisks indicate significantly stimulated $\mathrm{TNF} \alpha$ production $(P<0.01)$.

bacteria are not present during the process of luteolysis, we investigated other compounds that might stimulate macrophage action. One compound known to be involved in luteolysis is $\mathrm{PGF}_{2 \alpha}$ (Moeljono et al., 1976) and this eicosanoid can stimulate macrophage invasion in the corpus luteum (Hehnke et al., 1994) and also TNF production (Fig. 5). In pigs as well as in ruminants, PGF $_{2 \alpha}$ is known to be of endometrial origin (Moeljono et al., 1976) but it can also be produced by luteal cells (Patek and Watson, 1976). The eicosanoid is known to inhibit progesterone release from luteal cells under culture conditions (Pitzel et al., 1993a) but it also causes luteal regression when administered systemically; this effect is exerted only during the late luteal phase (Moeljono et al., 1976). Hence, it appears that the direct luteolytic effects of $\mathrm{PGF}_{2 \alpha}$ are augmented by its stimulatory effect on macrophage TNF $\alpha$ production. Indeed, increased expression of the gene encoding TNF $\alpha$ can be demonstrated in regressing corpora lutea (Fig. 6). The observation that the expression of the oestradiol receptor gene remains high (Fig. 3) and that of TNF $\alpha$ low (Fig. 6) in the corpus luteum of early pregnancy indicates that the early conceptus signals its presence by inhibiting expression of the gene encoding TNF $\alpha$ and therefore probably the action of TNF $\alpha$ is to reduce the luteotrophic oestrogenic machinery. The conceptuses may achieve this by inhibiting uterine $\mathrm{PGF}_{2 \alpha}$ secretion (Gross et al., 1988) and thereby preventing the stimulation of macrophage TNF $\alpha$ production. In 


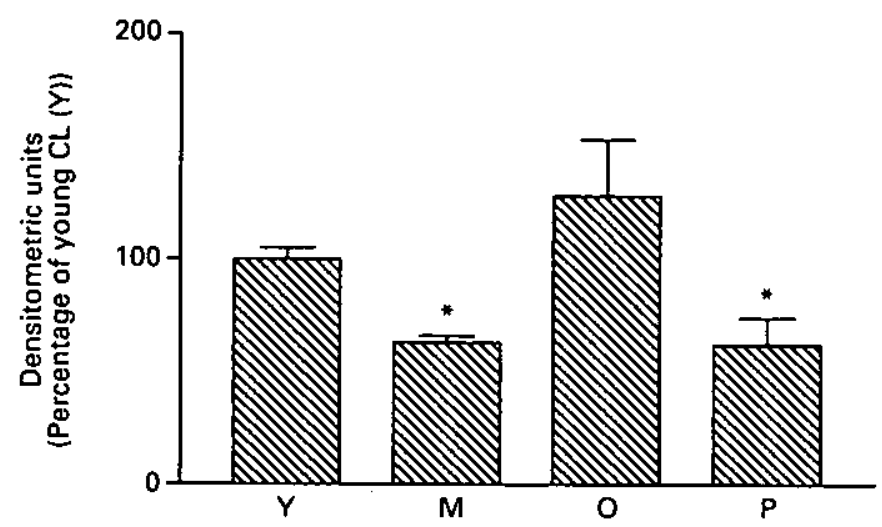

Fig. 6. Expression of the gene encoding TNF $\alpha$ in luteal tissue at various times of the luteal phase and in corpora lutea of early pregnancy. Note that expression of TNF $\alpha$ gene is highest at the time when the corpora lutea undergo luteolysis. The densitometric units indicating that TNF $\alpha$ gene expression obtained for PCR products of young corpora lutea (Y) were set as $100 \%$ and the other values were related accordingly. Asterisks indicate significantly $(P<0.05)$ lower expression of the TNF $\alpha$ gene in middle-aged (M) corpora lutea and in corpora lutea of pregnancy $(P)$. $\mathrm{O}$ : old regressing.

addition, we have preliminary evidence that another cytokine, namely interferone $\gamma$ which is of embryonic origin (La Bonnardière, 1993), has powerful luteotrophic effects that may override the potentially deleterious effects of remaining macrophage TNF production. To further our knowledge about whether TNF $\alpha$ shuts off the oestradiol-mediated luteotrophic effects, we studied the effects of TNF $\alpha$ on oestradiol production, aromatase activity and gene expression as well as on oestradiol receptor gene expression under cell culture conditions. TNF $\alpha$ has a profound inhibitory effect on luteal cell oestradiol secretion (Fig. 7); it inhibits aromatase activity as shown by the decreased oestradiol production by luteal cells when androstenedione (the precursor for oestradiol synthesis) is added to the culture media. Finally, Fig. 7 shows that expression of the gene encoding aromatase (the enzyme that converts androstenedione to oestradiol) as well as expression of the gene encoding the oestradiol receptor is profoundly inhibited by TNF $\alpha$. These data strongly suggest that TNF $\alpha$ not only exerts its luteolytic effects by a direct inhibition of progesterone secretion but that it also has strong anti-luteotrophic effects in that it inhibits the whole oestrogen machinery that is required for normal luteal function.

In summarizing this part of the review, we refer back to the ideas that were shown in Fig. 1 about how $\mathrm{PGF}_{2 \alpha}$ may stimulate progesterone secretion. It was noted that $\mathrm{PGF}_{2 \alpha}$ is a strong stimulator of oestradiol secretion (it also stimulates aromatase activity; (Pitzel et al., 1993) and this is essential for $\mathrm{PGF}_{2 \alpha}$ to be a luteotrophic signal. It has further been shown that TNF $\alpha$ inhibits not only oestradiol secretion but also aromatase activity and the expression of the oestrogen receptor gene. Hence all mechanisms by which $\mathrm{PGF}_{2 a}$ may indirectly stimulate progesterone secretion are largely abolished and this results in direct inhibition of progesterone secretion. Hence macrophage-derived cytokines, particularly TNF $\alpha$, are the signals that switch the action of $\mathrm{PGF}_{2 \alpha}$ from luteotrophic to luteolytic (Fig. 8).

\section{Functional Versus Structural Luteolysis ${ }^{. . \cdots}$}

Thus far only functional aspects of luteal regression have been discussed and it has been shown that TNF $\alpha$ is directly involved in reduced progesterone secretion by a direct inhibitory effect as well as by inhibiting the oestradiol-mediated luteotrophic effects. However, luteolysis involves not only 


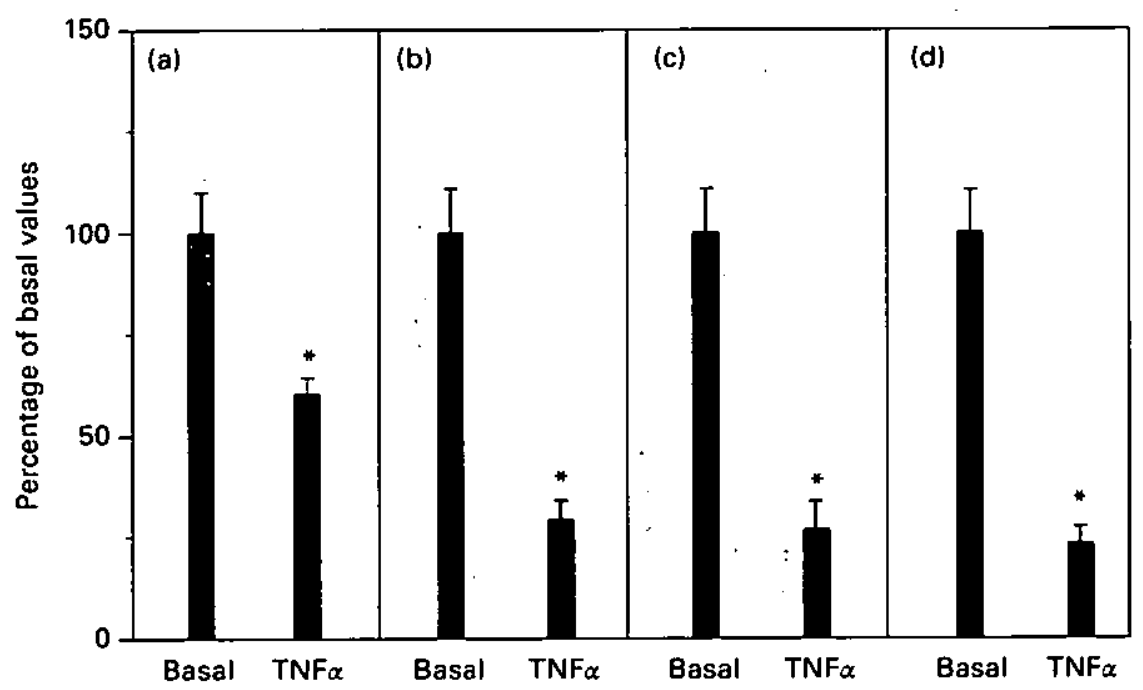

Fig. 7. Effects of TNF $\alpha$ on (a) oestradiol secretion (b) aromatase activity (c) aromatase gene expression and (d) oestrogen receptor gene expression of cultivated luteal cells. Note the strong inhibitory effect of TNF $\alpha$ on all of these parameters. In each case the mean basal values were set as $100 \%$ and the influence of TNF $\alpha$ is related to this. Asterisks indicate that $P<0.01$ versus the $100 \%$ values.

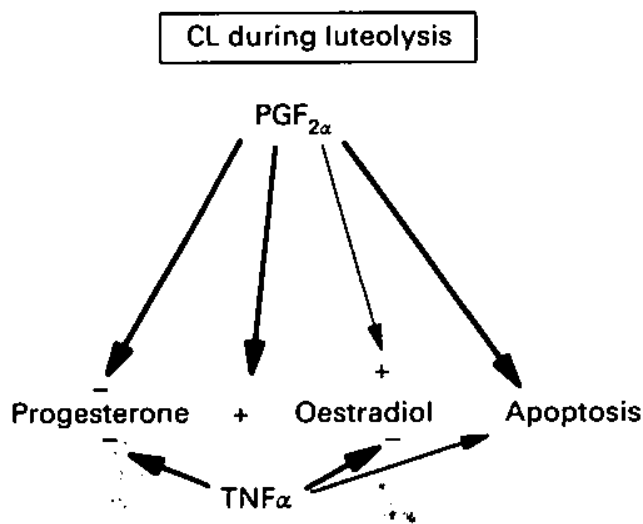

Fig. 8. During luteolysis TNF $\alpha$ inhibits the oestrogenic luteotrophic complex (aromatase activity, expression of the genes encoding aromatase and oestrogen receptor). Thereby the direct inhibitory action of $\mathrm{PGF}_{2 \mathrm{a}}$ and progesterone secretion becomes dominant. Therefore, the action of $\mathrm{PGF}_{2 a}$ (which in young corpora lutea is luteotrophic, see Figs 1 and 2) becomes luteolytic. In addition, TNF $\alpha$ also inhibits progesterone secretion. Both the eicosanoid and the cytokine induce apoptosis (see Fig. 10) and thereby also cause structural luteolysis. 


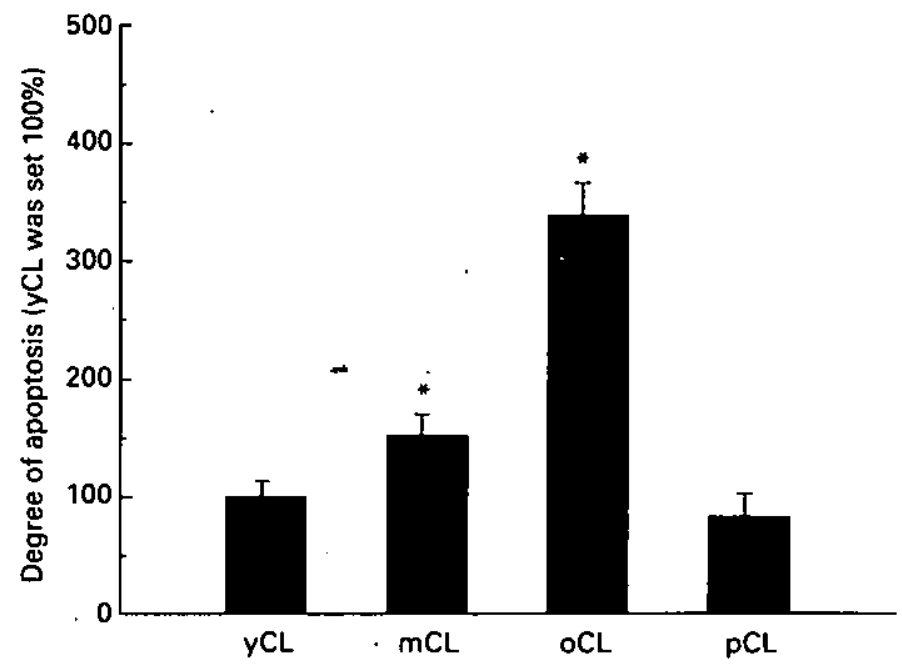

Fig. 9. Quantitative evaluation of apoptosis in corpora lutea obtained during the early (y), midluteal (m) phase and in regressing (o) corpora lutea. The densitometric units of DNA fragments obtained from yCL were set as $100 \%$ and the other values related accordingly. Note the much higher degree of apoptosis at the end of the luteal phase, which was not seen in the corpora lutea of pregnancy ( $p C L$ ). Asterisks indicate that values are significantly different from yCL.

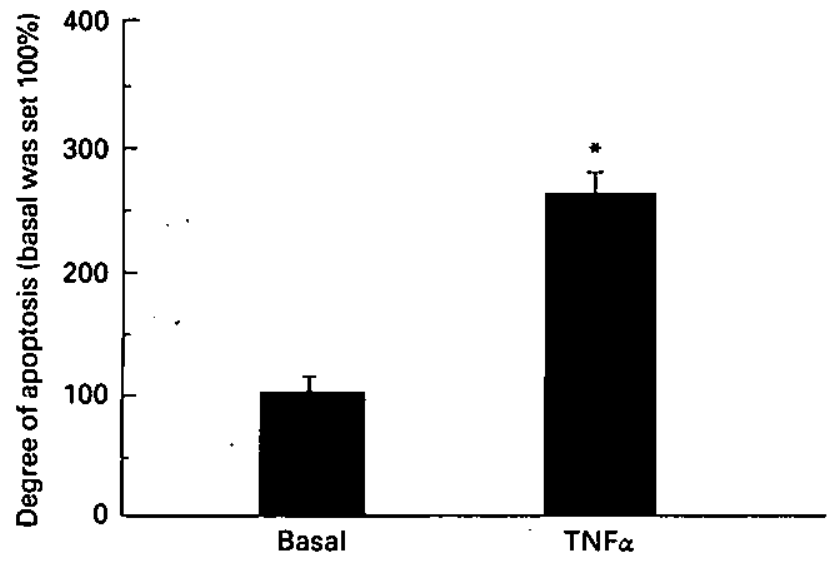

Fig. 10. Luteal cells were kept under culture conditions with or without TNF $\alpha\left(10^{-7} \mathrm{~mol} \mathrm{l^{-1 }}\right.$ for $\left.48 \mathrm{~h}\right)$. The cells were then harvested, the DNA subjected to electrophoresis and the DNA fragments measured densitometrically. Note that TNF $\alpha$ has a strong apoptotic effect compared with the basal degree of apoptosis. The basal level of apoptosis was set as $100 \%$ and the TNF $\alpha$-induced values related accordingly. The asterisk indicates a significant difference $(P<0.01)$ compared with the basal value. 
decreased steroid production but also morphological destruction of the corpus luteum, which is called structural luteolysis. As detailed above, TNF $\alpha$ is involved in functional luteolysis and it is possible that this cytokine may also induce structural luteolysis. Therefore, we studied the effects of TNF $\alpha$ on apoptotic processes. Apoptosis (programmed cell death) involves activation of an endonuclease (Juengel $e t$ al., 1993) that causes DNA sequestration into $180 \mathrm{bp}$ fragments. These DNA fragments can be electrophoretically separated and quantified by densitometry. Endonuclease activity is indeed higher in regressing corpora lutea than in young or middle aged corpora lutea (Fig. 9). Such an increased degree of apoptosis does not occur in corpora lutea of pregnancy (Fig. 9), again indicating that an embryonic signal prevents structural luteolysis. Under conditions in vitro, TNF $\alpha$ induces apoptosis (Fig. 10) which clearly demonstrates that this cytokine is involved not only in functional but also in structural luteolysis.

\section{Conclusion}

In summary, we have shown that the production of TNF $\alpha$ by macrophages can be stimulated by $\mathrm{PGF}_{2 \alpha}$ and that this cytokine has direct inhibitory effects on luteal function and on its structure. Furthermore, TNF $\alpha$ inhibits the expression and function of the oestrogenic luteotrophic machinery by inhibiting aromatase and oestradiol receptor gene expression as well as aromatase activity. Thereby, it inhibits PGF $_{2 \alpha}$ stimulated oestradiol production, which allows the eicosanoid to exert its direct luteolytic function and, in addition, TNF $\alpha$ itself inhibits progesterone secretion. Both the macrophage-derived cytokine TNF $\alpha$ and PGF $_{2 \alpha}$ also increase the degree of apoptosis, which is essential for morphological luteal regression.

\section{References}

Adashi EY, Resnick CE, Packman JN, Hurwitz A and Payne DW (1990) Cytokine-mediated regulation of ovarian function: tumor necrosis factor $\alpha$ inhibits gonadotropin-supported progesterone accumulation by differentiating and luteinized murine granulosa cells American Joumal of Obstetrics and Gynecology $162889-899$

Alila HW and Hansel W (1984) Origin of different cell types in the bovine corpus luteum as characterized by specific monoclonal antibodies Biology of Reproduction 31 1015-1025

Brannian JD, Stouffer RL, Shiigi SM and Hoyer PB (1993) Isolation of ovine cell subpopulations by flow cytometry Biology of Reproduction 48 495-502

Chandrasekher YA, Melner MH, Nagalla S and Stouffer RL, (1994) Progesterone receptor, but not estradiol receptor, messenger ribonucleic acid is expressed in luteinizing granulosa cells and the corpus luteum in rhesus monkeys Endocrinology 135 307-314

Conley AJ and Ford SP (1989) Direct luteotrophic effect of estradiol-17B on pig corpora lutea journal of Reproduction and Fertility 87 125-131

Fitz TA, Mayan MH, Sawyer HR and Niswender GD (1982) Characterization of two steroidogenic cell types in the ovine corpus luteum Biology of Reproduction 27 703-711

Gross TS, Lacroix MC, Bazer FW, Thatcher WW and Harney JP (1988) Prostaglandin secretion by perifused porcine endometrium: further evidence for an endocrine versus exocrine secretion of prostaglandins Prostaglandins 35 327-341

Hehnke KE, Christenson LK, Ford SP and Taylor M (1994) Macrophage infiltration into the porcine corpus luteum

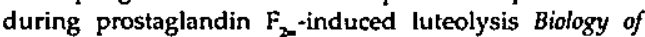
Reproduction 50 10-15
Hild-Petito S, Stouffer RL and Brenner RM (1988) Immunocytochemical localization of estradiol and progesterone receptors in the monkey ovary throughout the menstrual cycle Endocrinology 123 2896-2905

Jarry H, Düker E-M and Wuttke W (1985) Adrenal release of catecholamines and metenkephalin before and after stress as measured by a novel in vivo dialysis method in the rat Neuroscience Letters $60273-278$

Jarry H, Einspanier A, KanngieBer L, Dietrich M, Pitzel L., Holtz W and Wuttke $W(1990)$ Release and effects of oxytocin on estradiol and progesterone secretion in porcine corpora lutea as measured by an in vivo microdialysis system Endocrinology 126 2350-2358

Juengel JL, Garverick A, Johnson AL, Youngquist RS and Smith MF (1993) Apoptosis during luteal regression in cattle Endocrinology 132 249-254

Kennedy RL and Jones TH (1991) Cytokines in endocrinology: their roles in health and in disease Joumal of Endocrinology 129 167-178

Kirsch TM, Friedman AC, Vogel RL and Flickinger GL (1981) Macrophages in corpora lutea of mice: characterization and effects on steroid secretion Biology of Reproduction 25 $629-638$

La Bonnardière C (1993) Nature and possible functions of interferons secreted by the preimplantation pig blastocyst Journal of Reproduction and Fertility Supplement 48 157-170

Moeljono PME, Bazer FW and Thatcher WW (1976) A study of prostaglandin $F_{2 a}$ as the luteolysin in swine: $I$. Effect of prostaglandin $\mathrm{F}_{2 a}$ in hysterectomized gilts Prostaglandins 11 737-743

O'Shea JD, Rodgers RJ and Wright PJ (1986) Cellular composition of the sheep corpus luteum in the mid- and 
late luteal phases of the cestrous cycle fournal of Reproduction and Fertility 76 685-691

Patek CE and Watson J (1976) Prostaglandin F and progesterone secretion by poncine endometrium and corpus luteum in vitro. Prostaglandins 12 97-111

Pitzel L, Jarry $\mathrm{H}$ and Wuttke $W(1990)$ Effects of axytocin on in vitro steroid release of midstage small and large porcine luteal cells Endocrinology 126 2343-2349

Pitzel L, Jarry $\mathbf{H}$ and Wuttke W (1993a) Different steroidogenic response of young and aged porcine small and large luteal cells to prostaglandin $F_{2 m}$, oxytocin, and estradiol Experimental and Clinical. Endocrinology \& Diabetes 101 255-261

Pitzel L, Jarry $\mathrm{H}$ and Wuttke W (1993b) Effects and interactions of PGF $_{2 x}$ oxytocin and cytokines on steroidogenesis of porcine luteal cells Endocrinology 132 751-756

Pusateri AE, Smith JM, Smith II JW, Thomford PJ and Diekman MA (1996) Materrial recognition of pregnancy in swine. I. Minimal requirement for exogenous estradiol-17B to induce either short or long pseudopregnancy in cycling gilts Biology of Reproduction 55 582-589
Schwall RH, Sawyer HR and Niswender GD (1986) Differential regulation by $\mathrm{LH}$ and prostaglandins of steroidogenesis in small and large luteal cells of the ewe joumal of Reproduction and Fertility $76821-829$

Shaw DW and Britt JH (1995) Concentrations of tumor necrosis factor alpha and progesterone within the bovine corpus luteum sampled by continuous-flow microdialysis during luteolysis in vito. Biology of Reproduction 53 847-854

Theiling K, Knoke I, Jarry $H$ and Wuttke $W$ (1996) Demonstration of estrogen and progesterone receptor gene expression in porcine luteal cells. In Program \& Abstracts Vol. Il, 10th International Congress of Endocrinology (ICE 96), P3-330, p. 837

Wuttke W, Jarry H, Knoke I, Pitzel L and Spiess S ( 1995) Luteotrophic and luteolytic effects of oxytocin in the porcine corpus luteum. In Oxytocin, Cellular and Molecular Approaches in Medicine and Research pp 495-506 Eds R Ivell and A Russell. Plenum Press, New York 